\title{
IDENTIFIKASI POPULASI BAKTERI DALAM SPONS PENCUCI PIRING DENGAN METODE PCR-RFLP
}

\section{IDENTIFICATION OF BACTERIA POPULATION IN DISHWASHING SPONGE USING PCR-RFLP METHOD}

\author{
*Shabarni-Gaffar, Iman Permana Maksum \& Euis Julaeha \\ Jurusan Kimia FMIPA Universitas Padjadjaran \\ Jl. Raya Bandung-Sumedang Km.21 Jatinangor, Sumedang, Jawa Barat 45363 \\ *Alamat korespondensi: sabarni.ghafar@unpad.ac.id atau era2504@yahoo.com
}

\begin{abstract}
Abstrak: Spons pencuci piring 200.000 kali lebih kotor dibanding dudukan toilet. Berbagai bakteri penyebab penyakit seperti Eschericia coli, Pseudomonas dan Staphylococcus, berkembang biak di permukaan yang basah. Selain itu, 500 ribu bakteri hidup di dalam saluran pembuangan bak cuci piring. Jika spons dalam kondisi tidak kering (lembab karena direndam), maka akan menjadi markas semua bakteri. Penelitian ini bertujuan untuk menentukan populasi bakteri yang terdapat pada spons cuci piring yang basah. Identifikasi dilakukan dengan metoda molekular berbasis DNA yaitu teknik PCR-RFLP gen 16s rDNA. Metoda PCR-RFLP merupakan genetik fingerprinting yang akurat, cepat dan sederhana. Koloni bakteri yang ditumbuhkan dari spons pencuci piring di lisis dan digunakan sebagai templat untuk PCR. Hasil PCR gen 16s rDNA yang berukuran 1400 pb, dipotong dengan enzim restriksi, Hinf1. Hasil penelitian menunjukkan terdapat empat pola pemotongan yang berbeda-beda. Pola yang berbeda ini menunjukkan terdapat empat populasi yang berbeda hidup pada spons basah. Kami mengidentifikasi bahwa salah satu mikroba yang tumbuh adalah E. coli yang merupakan bakteri patogen.
\end{abstract}

\section{Kata kunci: Spons, PCR-RFLP, 16s rDNA}

\begin{abstract}
Dishwashing sponge is 200.000 times dirtier than a toilet seat. A variety of disease-causing bacteria such as Eschericia coli, Pseudomonas and Staphylococcus breeds in the wet surfaces. In addition, fifty hundred and thousand bacteria live in the sewer sink. If a sponge is in wet conditions (moist due to soaked), it will become the headquarters of many bacteria. This study aims to determine the bacterial populations found in wet dishwashing sponge. The identification was carried out by molecular DNA-based approaches, that is PCRRFLP of 16s rDNA gene. PCR-RFLP is an accurate, quick and simple genetic finger printing method. Bacterial colonies which is grow from dishwashing sponge was lysed and used as a template for PCR reaction. The PCR product wasl6s rDNA gene sized $1400 \mathrm{bp}$, then it was cut using Hinfl restriction enzyme. The result obtained four different pattern of cutting. Variation in cutting patterns indicated that there were four different populations of microbes live in the wet sponge. We identified that one of the microbes that live is E. coli which is pathogenic bacteria.
\end{abstract}

\section{Keywords: Sponge, PCR-RFLP, 16s rDNA}

\section{PENDAHULUAN}

Pengklasifikasian, identifikasi dan typing mikroorganisme merupakan hal yang penting dilakukan pada studi kasus epidemiologi rumah sakit, medis, lingkungan, industri dan pertanian serta untuk mempelajari ekologi mikroba (Summarco, et al., 2014). Metode untuk karakterisasi mikroba secara tradisional berdasarkan pada fenotipe (Woese, 1987; Madigan et al., 2000). Fingerprinting DNA berbasis metoda PCR merupakan suatu metoda yang akurat, cepat dan sederhana untuk mengkarakterisasi dan membedakan populasi mikroba. Sejumlah metoda genotyping telah tersedia dan digunakan untuk typing, identifikasi dan klasifikasi mikroba. Masing masing metoda memiliki keuntungan dan kekurangan tersendiri (Savelkoul et al., 1999).

Klasifikasi organisme pada umumnya didasarkan pada karakter morfologis sebagai indikator hubungan genetik (Woese, 1987), tetapi saat ini ada kecenderungan untuk menggunakan pendekatan baru yang dapat melengkapi sistem klasifikasi yang ada, seperti misalnya melalui chemotaxonomy maupun melalui pendekatan molekuler.

Metode PCR-based typing dapat digunakan untuk studi ekologi mikroba. Contohnya adalah karakterisasi bakteri yang ditemukan pada mulut, lambung dan kulit manusia. PCR-based typing juga sering digunakan untuk studi ekologi mikroba pada peralatan makanan (seperti spons pencuci piring), makanan hewan, dan lingkungan yang berhubungan dengan manusia, baik langsung maupun tidak langsung (Kolbert et al., 1999).

Metoda identifikasi mikroba secara molekuler yang sangat popular adalah identifikasi menggunakan gen SSU (small subunit) rRNA yaitu; 16S rRNA untuk prokaryota dan gen 18S rRNA untuk 
eukaryota. RNA ribosom (rRNA) digunakan sebagai kronometer molekul karena RNA ribosom adalah molekul purbakala, fungsinya konstan, terdistribusi secara universal, dan urutannya cukup "conserved" diantara jarak filogenetik yang luas. Selain itu, karena jumlah kemungkinan urutan yang berbeda, dari molekul yang besar seperti RNA ribosom sangat besar, kesamaan antara dua urutan sering menggambarkan beberapa hubungan filogenetik. Tingkat kesamaan urutan RNA ribosom antara dua organisme, menggambarkan hubungan evolusi relatif diantara dua organisme tersebut. SSU rRNA merupakan rRNA yang sering digunakan untuk menggambarkan hubungan filogenetik. Dengan ukuran 1600-2000 pasang basa, cukup menyediakan informasi yang digunakan untuk menggambarkan hubungan evolusi antara sekuen yang dibandingkan (Baker, 2001; Woese, 1987; Olsen \& Woese, 1993).

Metoda Polimerase Chain Reaction (PCR) digunakan untuk mengamplifikasi gen pengode 16S/18S rRNA dari DNA genom (Newton \& Graham, 1994). Hasil PCR ditentukan urutannya dengan sekuensing metoda dideoksi Sanger. Hasil sekuensing gen 16s rDNA dapat dianalisis dengan membandingkannya dengan database yang ada sehingga identitas bakteri dapat dianalisis menggunakan program komputer.

Penentuan urutan DNA biasanya memakan waktu yang cukup lama, karena persiapan sampel yang harus cukup murni dan tidak tersedianya peralatan sekuensing DNA di Laboratorium yang sederhana. Maka sebagai tahap awal untuk mengetahui populasi dapat digunakan metoda RFLP.

RFLP (Restriction Fragment Length Polymorphism) merupakan teknik pemotongan fragmen DNA homolog dengan enzim restriksi menghasilkan fragmen DNA dengan ukuran yang berbeda-beda antara satu alel dengan alel lainnya, sehingga akan menggambarkan polimorfisme pada urutan DNA homolog. Polimorfisme pada DNA ditunjukkan oleh variasi ukuran fragmen DNA bila dipotong dengan enzim restriksi yang dapat dianalisis dengan gel elektroforesis. Adanya variasi ukuran fragmen DNA secara tidak langsung akan menunjukkan adanya polimorfisme pada DNA. Teknik ini dapat membedakan sampel molekul DNA homolog berdasarkan ukuran dan jumlah fragmen hasil restriksi yang dihasilkan. Pada analisis PCRRFLP, fragmen DNA hasil PCR dipotong dengan enzim restriksi, fragmen DNA hasil restriksi dipisahkan dengan elektroforesis agarosa (Schutte et al., 2008; Brugger et al., 2012).

Analisis RFLP merupakan teknik DNA profiling yang murah, yang digunakan sebagai dasar metoda genetic fingerprinting dan dapat digunakan untuk aplikasi yang luas seperti: forensik, test keibuan/kebapaan, genetik diversitas, ekologi mikroba dan evolusi manusia. Teknik ini juga dapat digunakan sebagai analisis pendahuluan sebelum penggunaan teknik sekuensing DNA (Nocker et al., 2007).

Baker et al. (2001), menggunakan sepasang primer yaitu BactF1 dan UniB, untuk mengamplifikasi 1400 pasang basa fragmen gen $16 \mathrm{~s}$ rDNA. Primer ini telah berhasil digunakan untuk mengamplifikasi dan mengidentifikasi bakteri dari sumber air panas di Bandung, Indonesia. Pasangan primer ini digunakan untuk tujuan identifikasi populasi bakteri yang hidup pada spons pencuci piring. Penelitian ini akan memberikan informasi jumlah populasi bakteri yang hidup pada spons pencuci piring.

\section{BAHAN DAN METODE}

Penumbuhan bakteri menggunakan bahan; bakto agar, tripton, ekstrak ragi dan $\mathrm{NaCl}$. Lisis bakteri menggunakan buffer Tris-EDTA. Proses PCR menggunakan; enzim Taq DNA polimerase, buffer PCR 10x, $\mathrm{MgCl}_{2}$, dNTP, primer BactF1dan UniB1 serta aquabidest. Proses elektroforesis menggunakan; agarose, buffer TAE 1x (Tris-Asetat-EDTA), EtBr, loading buffer, DNA marker 1000 pb. Pemurnian DNA menggunakan; etanol p.a, dan natrium asetat. Pereaksi restriksi menggunakan; enzim Hinf1, buffer restriksi dan aquabidest

\section{Pembuatan media pertumbuhan.}

Media LB (Luria Bertani) cair dibuat dengan mencampurkan $0,5 \%$ (b/v) ekstrak ragi, $1 \%$ (b/v) tripton dan $1 \%(\mathrm{~b} / \mathrm{v})$ natrium klorida. Campuran dilarutkan dengan air distilasi dan disterilisasi selama15 menit menggunakan autoclave. Untuk media padat komposisi sama dengan media cair dan ditambah bakto agar $2 \%$.

\section{Penumbuhan bakteri dari spons pencuci piring.}

Spons pencuci piring yang telah dibiarkan semalam dalam larutan sabun, dipotong menggunakan gunting steril dengan ukuran $\pm 0,5 \mathrm{~cm}^{2}$, kemudian dimasukkan kedalam media LB cair $5 \mathrm{~mL}$, dan diinkubasi dalam inkubator pengocok pada suhu $37^{\circ} \mathrm{C}$ dengan pengocokan $150 \mathrm{rpm}$ selama 24 jam.

\section{Total Plate Counting (TPC).}

Sebanyak $1 \mathrm{~mL}$ kultur bakteri dari media cair dicampur secara steril dengan $9 \mathrm{~mL} \mathrm{NaCl}$ fisiologis, dicampur untuk mengaduk untuk memperoleh kultur dengan pengenceran $10^{-1}$, kemudian diambil $1 \mathrm{~mL}$ dan dicampur dengan $9 \mathrm{~mL} \mathrm{NaCl}$ fisiologis untuk memperoleh pengenceran $10^{-2}$, demikian dilakukan sampai diperoleh kultur dengan pengenceran $10^{-8}$. Kultur dengan pengenceran $10^{-6}, 10^{-7}$ dan $10^{-8}$, ditumbuhkan ke media LB padat, dengan cara: $1 \mathrm{~mL}$ kultur diambil, dimasukkan ke cawan petri kosong, kemudian ditambahkan $\pm 20 \mathrm{~mL}$ media LB padat yang masih hangat. Kultur dibiarkan membeku, setelah dingin diinkubasi pada $37^{\circ} \mathrm{C}$ selama 24 jam. Keesokan harinya jumlah koloni yang tumbuh dihitung dan diamati morfologinya. 


\section{Lisis Bakteri.}

Koloni bakteri dilisis secara cepat dengan cara mengambil sedikit bagian dari koloni bakteri secara steril dan memasukkannya kedalam tabung $1,5 \mathrm{~mL}$ yang telah berisi $40 \mu \mathrm{L}$ buffer TE $\mathrm{pH}$ 8. Suspensi sel dididihkan selama 10 menit, kemudian di spin menggunakan mikrosentrifuge pada kecepatan 8000 x g selama 10 menit. Sebanyak $10 \mu \mathrm{L}$ supernatan digunakan sebagai templat proses PCR.

\section{Amplifikasi fragmen gen 16s rRNA.}

Fragmen DNA gen 16s rDNA diamplifikasi menggunakan teknik PCR. Campuran reaksi terdiri dari: $10 \mu \mathrm{L}$ hasil lisis, enzim Taq DNA Polimerase 2,5 Unit, buffer PCR 1x, $20 \mu \mathrm{M}$ masing-masing primer BactF1 dan UniB1, $3 \mathrm{mM} \mathrm{MgCl}_{2}$ dan air steril. Proses PCR dilakukan dalam mesinMastercycler® 5330 (Eppendorf). Siklus PCR dimulai dengan denaturasi awal pada $95^{\circ} \mathrm{C}$ selama 5 menit, diikuti dengan 30 siklus : $\left(95^{\circ} \mathrm{C}\right.$ selama 1 menit; $50^{\circ} \mathrm{C}$ selama 1 menit; $70^{\circ} \mathrm{C}$ selama 1 menit) dan pemanjangan akhir pada $70^{\circ} \mathrm{C}$ selama 10 menit. Produk PCR kira-kira berukuran $1.4 \mathrm{~kb}$ di analisis menggunakan elektroforesis gel agarosa $1 \%$.

\section{Karakterisasi hasi PCR dengan elektroforesis gel agarose.}

Hasil PCR dianalisis dengan cara elektroforesis pada gel agarosa $1 \%(\mathrm{~b} / \mathrm{v})$ yang dibuat dengan melarutkan $1 \%$ agarosa dalam $40 \mathrm{~mL}$ buffer TAE (40 mM Tris$0,11 \%$ AS asetat; dan $1 \mathrm{mM}$ EDTA). Larutan dipanaskan hingga agarosa larut sempurna, lalu didinginkan hingga suhu $60^{\circ} \mathrm{C}$ dan ditambahkan $2 \mu \mathrm{L}$ etidium bromida $10 \mathrm{mg} / \mathrm{mL}$. Campuran dikocok sampai homogen kemudian dituangkan kedalam cetakan gel berukuran $6 \times 10 \mathrm{~cm}$ yang telah dilengkapi dengan sisir untuk mencetak sumur gel. Gel yang masih berupa cairan dibiarkan hingga membeku sempurna. Gel yang telah membeku siap digunakan untuk elektroforesis. Sebanyak $10 \mu \mathrm{L}$ sampel hasil PCR dicampurkan dengan $2 \mu \mathrm{L}$ loading buffer $(40 \%$ sukrosa; $0,25 \%$ bromfenol biru). Campuran dihomogenkan dengan cara dipipet naik turun berkali-kali lalu dimasukkan ke dalam sumur gel agarosa $1 \% \quad(\mathrm{~b} / \mathrm{v})$. Elektroforesis dilakukan menggunakan alat Mini Sub Cell (Biorad) dengan tegangan 70 volt selama 45-50 menit dan menggunakan buffer TAE sebagai media pengantar arus. Sebagai standar ukuran DNA digunakan DNA ladder $1 \mathrm{~kb}$. Pita DNA dilihat dengan bantuan sinar ultra violet.

\section{Pemurnian produk PCR.}

Produk PCR dipindahkan kedalam tabung 1,5 mL. Tentukan total volume sampel yang terkumpul. Etanol p.a ditambahkan ke dalam tabung sebanyak 2 $\mathrm{x}$ volume sampel hasil PCR, dan $0,1 \mathrm{x}$ volume natrium asetat $3 \mathrm{M} \mathrm{pH} 7$. Inkubasi pada suhu $-20^{\circ} \mathrm{C}$ semalam. Keesokan harinya, sentrifugasi pada suhu $4^{\circ} \mathrm{C}$, kecepatan $\sim 12.000 \mathrm{rpm}$ selama 30 menit.
Supernatan dibuang dengan cara dekantasi, pelet dicuci dengan menambahkan etanol $70 \%$ dingin sebanyak $5 \mathrm{x}$ volume, kemudian diinversi beberapa kali. Sentrifugasi kembali pada suhu $4^{\circ} \mathrm{C}$, kecepatan $12.000 \mathrm{rpm}$ selama 10 menit. Supernatan dibuang dengan cara dekantasi dan pelet dikeringkan dengan menggunakan konsentrator vakum pada $30^{\circ} \mathrm{C}$ selama 15-30 menit. Setelah pelet kering, ditambahkan 20 $\mu \mathrm{L}$ akuabidest steril dan dipipet sampai semua DNA terlarut kembali. Konsentrasi fragmen DNA hasil PCR yang telah dimurnikan dapat ditentukan dengan biofotometer UV atau diperkirakan dengan cara elektroforesis gel agarose $1 \%(\mathrm{~b} / \mathrm{v})$, tegangan 80 volt, selama 30-60 menit.

\section{Pemotongan produk PCR dengan enzim Hinf1.}

Sebanyak $20 \mu \mathrm{L}$ hasil pemurnian produk PCR ditambahkan $2 \mu \mathrm{L}$ buffer HinfI 10x, $1 \mu \mathrm{L}$ enzim EcoRI (10 U/mL), dan air bebas nuklease hingga volume total reaksi $20 \mu \mathrm{L}$. Kemudian diinkubasi pada suhu $37^{\circ} \mathrm{C}$ selama 2 jam. Setelah itu dikarakterisasi dengan elektroforesis agarose.

\section{Interpretasi Data.}

Data hasil PCR-RFLP dianalisis dengan membandingkan hasil pemotongan fragmen PCR dengan enzim restriksi dari beberapa koloni bakteri yang diuji.

\section{HASIL DAN PEMBAHASAN}

Penumbuhan bakteri dari spons pencuci piring.

Untuk mengidentifikasi populasi bakteri yang tumbuh pada spons pencuci piring, penelitian yang dilakukan dimulai dengan pengkulturan bakteri dari spons pencuci piring. Spons pencuci piring yang telah direndam selama semalam, dipotong menggunakan gunting steril, kemudian dimasukkan kedalam media cair Luria Bertani, dan diinkubasi selama semalam pada suhu $37^{\circ} \mathrm{C}$ dengan pengocokan pada $150 \mathrm{rpm}$. Gambar 1 memperlihatkan spons pencuci piring yang digunakan dan bakteri yang tumbuh pada media cair.

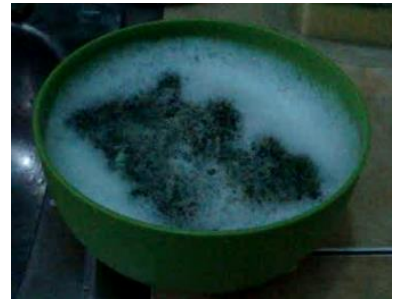

A

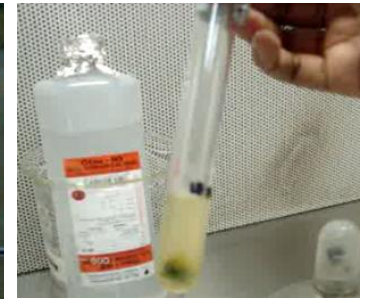

B
Gambar 1.(A) Spons pencuci piring yang direndam dalam larutan sabun selama semalam. (B) Kultur bakteri yang tumbuh dari spons pencuci piring menggunakan media cair Luria Bertani.

\section{Total Plate Counting (TPC).}

Untuk mengetahui populasi bakteri yang tumbuh pada spons maka bakteri dari media cair dipindahkan 
ke media padat dengan pengenceran menggunakan $\mathrm{NaCl}$ fisiologis. Sebanyak $1 \mathrm{~mL}$ kultur bakteri dari media cair dicampur secara steril dengan $9 \mathrm{~mL} \mathrm{NaCl}$ fisiologis, dicampur untuk mengaduk untuk memperoleh kultur dengan pengenceran $10^{-1}$, kemudian diambil $1 \mathrm{~mL}$ dan dicampur dengan $9 \mathrm{~mL}$ $\mathrm{NaCl}$ fisiologis untuk memperoleh pengenceran $10^{-2}$, demikian dilakukan sampai diperoleh kultur dengan pengenceran $10^{-8}$. Kultur dengan pengenceran $10^{-6}$, $10^{-7}$ dan $10^{-8}$, ditumbuhkan ke media LB padat, Keesokan harinya jumlah koloni yang tumbuh dihitung dan diamati morfologinya.

Hasil pengamatan memperlihatkan tumbuh sejumlah koloni bakteri dengan morfologi yang berbeda. Berdasarkan pengamatan dengan mata telanjang, kami mengamati terdapat tiga jenis morfologi yang berbeda. Jumlah koloni bakteri yang tumbuh dihitung dan diperoleh sejumlah 8 koloni tumbuh pada media dengan pengenceran $10^{-8}$. Sehingga berdasarkan perhitungan jumlah total koloni yang terdapat pada $1 \mathrm{~mL}$ media cair adalah 3,1 $\mathrm{x} 10^{8}$ cfu (colony forming unit). Gambar 2 memperlihatkan koloni bakteri yang tumbuh pada media padat Luria Bertani.

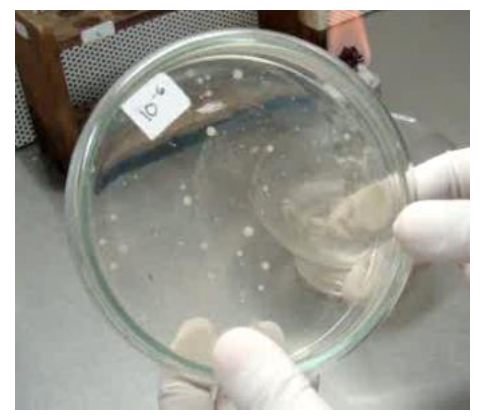

Gambar 2. Koloni-koloni bakteri yang tumbuh pada media padat Luria Bertani.

\section{Lisis bakteri.}

Lisis bertujuan untuk merusak dinding sel bakteri sehingga semua komponen yang terdapat di dalam sel terpapar keluar. Lisis dengan cara pendidihan dalam buffer Tris-EDTA pH 7 merupakan metoda lisis cepat untuk merusak dinding sel bakteri gram negatif maupun positif. Beberapa koloni bakteri dipilih, dan diambil secara steril menggunakan tusuk gigi steril, kemudian dimasukkan ke dalam $40 \mu \mathrm{L}$ buffer TE. Campuran dididihkan selama 10 menit, selanjutnya disentrifugasi pada kecepatan maksimum selama 10 menit untuk memisahkan debris sel dari supernatan. Supernatan digunakan sebagai templat untuk proses PCR. Sebagai pembanding, dilisis juga bakteri $E$. coli.

\section{Amplifikasi fragmen gen 16s rDNA dengan metoda PCR.}

Amplifikasi fragmen gen 16s rDNA dengan metoda PCR dilakukan menggunakan pasangan primer BactF1 dan UniB1 (Baker et al., 2001). PCR menggunakan pasangan primer ini akan menghasilkan fragmen gen 16s rDNA dengan ukuran $\sim 1400 \mathrm{pb}$.

Campuran reaksi terdiri dari: $10 \mu \mathrm{L}$ hasil lisis (sumber DNA templat), enzim Taq DNA Polimerase 2,5 Unit, buffer PCR 1x, $20 \mu \mathrm{M}$ masing-masing primer BactF1 dan UniB1, 2,5 $\mathrm{mM} \mathrm{MgCl}_{2}$ dan air steril, sehingga volume total $50 \mu \mathrm{L}$. Untuk memudahkan dan menghindari terjadinya kesalahan pemipetan maka dibuat master mix untuk 10 reaksi PCR yang mengandung semua komponen reaksi kecuali templat hasil lisis. Master mix dibagi ke dalam 10 tabung yang masing-masingnya mengandung $40 \mu \mathrm{L}$ pereaksi, kemudian ditambahkan $10 \mu \mathrm{L}$ templat hasil lisis ke dalam tabung yang berbeda. Proses PCR dilakukan menggunakan alat Master cycler (Eppendorf). Siklus PCR dimulai dengan denaturasi awal pada $95^{\circ} \mathrm{C}$ selama 5 menit, diikuti dengan 30 siklus: $\left(95^{\circ} \mathrm{C}\right.$ selama 1 menit; $50^{\circ} \mathrm{C}$ selama 1 menit; $70^{\circ} \mathrm{C}$ selama 1 menit) dan pemanjangan akhir pada $70^{\circ} \mathrm{C}$ selama 10 menit. Alat PCR dilengkapi dengan "lid" pada bagian tutupnya yang berfungsi sebagai pemanas dengan suhu $104^{\circ} \mathrm{C}$, sehingga larutan yang menguap pada proses pemanasan akan segera mengembun kembali, sehingga larutan dalam tabung PCR tidak akan berkurang.

\section{Karakterisasi hasil PCR dengan elektroforesis agarose.}

Hasil PCR dianalisis dengan elektroforesis horizontal menggunakan media gel agarose $1 \%$. Elektroforesis dilakukan menggunakan alat Mini Sub Cell (Biorad) dengan tegangan 70 volt selama 45-50 menit dan menggunakan buffer TAE sebagai media pengantar arus. Sebagai standar ukuran DNA digunakan DNA ladder $1 \mathrm{~kb}$. Pita DNA dilihat dengan bantuan sinar ultra violet. Hasil elektroforesis yang diperlihatkan pada Gambar 3 menunjukkan proses PCR berhasil dilakukan dengan diperolehnya pita dengan ukuran $\sim 1400 \mathrm{pb}$.

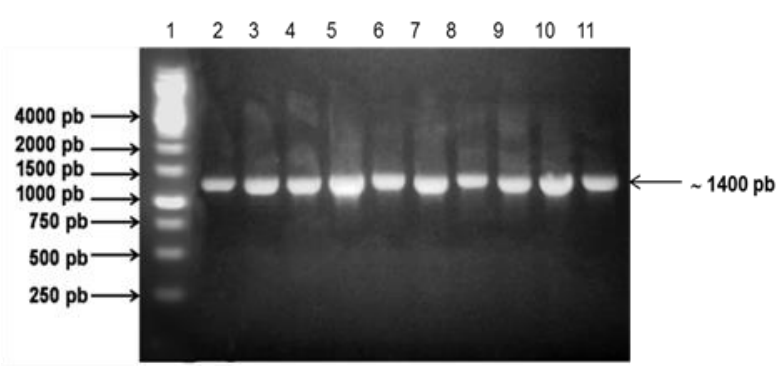

Gambar 3.Hasil elektroforesis produk PCR; lajur 1 Marka DNA, lajur 2-11 hasil PCR dengan ukuran $\sim 1400 \mathrm{pb}$.

\section{Pemurnian produk PCR.}

Pemurnian produk PCR dilakukan dengan metoda presipitasi etanol yang bertujuan untuk memurnikan produk PCR dari sisa sisa pereaksi PCR seperti enzim Taq DNA polimerase, sisa primer dan dNTP. 
Etanol p.a ditambahkan ke dalam tabung sebanyak 2 $\mathrm{x}$ volume sampel hasil PCR, dan $0,1 \mathrm{x}$ volume natrium asetat $3 \mathrm{M}$ pH 7. Campuran diinkubasi pada suhu $-20^{\circ} \mathrm{C}$ semalam, kemudian dicuci dengan etanol $70 \%$ dingin. DNA adalah molekul polar karena adanya tulang punggung fosfat yang bermuatan negatif, sehingga DNA larut dalam air. Penambahan kation kedalam larutan DNA tidak akan menghasilkan endapan garam karena pembentukan ikatan ion dihalangi oleh molekul air. Etanol kurang polar dibandingkan air, sehingga penambahan kation $\mathrm{Na}^{+} \mathrm{ke}$ dalam larutan DNA dalam etanol $100 \%$ akan mengendapkan DNA. Semua proses sentrifugasi pada tahap ini dilakukan pada suhu $4^{\circ} \mathrm{C}$. Presipitan DNA dikeringkan dengan menelungkupkannya di atas tissue atau menggunakan alat vacuum concentrator (Eppendorf). DNA yang sudah kering, kemudian di larutkan dalam $20 \mu \mathrm{L}$ aquabidest.

\section{Pemotongan produk PCR dengan enzim Hinf1.}

Studi RFLP fragmen gen 16s rDNA hasil PCR dilakukan melalui pemotongan dengan enzim Hinf1. Enzim ini dipilih karena berdasarkan Baker et al. (2001), enzim ini berhasil digunakan untuk membedakan populasi mikroba yang terdapat pada sumber air panas di Bandung, Indonesia. Sebanyak $10 \mu \mathrm{L}$ hasil pemurnian produk PCR ditambahkan 2 $\mu \mathrm{L}$ buffer HinfI $10 \mathrm{x}, 1 \mu \mathrm{L}$ enzim HinfI $(10 \mathrm{U} / \mathrm{mL})$, dan air bebas nuklease hingga volume total reaksi 20 $\mu \mathrm{L}$. Kemudian diinkubasi pada suhu $37^{\circ} \mathrm{C}$ selama 2 jam. Setelah itu dikarakterisasi dengan elektroforesis gel agarose seperti diatas.

Hinf1 merupakan enzim restriksi endonuklease yang mengenali urutan 5'-GANTC-3' dengan pemotongan menghasilkan ujung lancip setelah basa 5 '-G. Hasil pemotongan fragmen 16 s rDNA dengan enzim Hinf1 dikarakterisasi dengan gel agarose (Gambar 4). Berdasarkan hasil analisis RFLP menggunakan enzim Hinf1 ini diperkirakan terdapat empat jenis populasi bakteri yang tumbuh pada spons pencuci piring, dimana salah satunya adalah $E$. coli karena ukuran dan pola pemotongannya sama dengan sampel E. coli.

RFLP (Restriction Fragment Length Polymorphism) merupakan teknik pemotongan fragmen DNA homolog dengan enzim restriksi menghasilkan fragmen DNA dengan ukuran yang berbeda-beda antara satu alel dengan alel lainnya, sehingga akan menggambarkan polimorfisme pada urutan DNA homolog.

Polimorfisme pada DNA ditunjukkan oleh variasi ukuran fragmen DNA bila dipotong dengan enzim restriksi yang dapat dianalisis dengan gel elektroforesis. Adanya variasi ukuran fragmen DNA secara tidak langsung akan menunjukkan adanya polimorfisme pada DNA. Teknik ini dapat membedakan sampel molekul DNA homolog berdasarkan ukuran dan jumlah fragmen hasil restriksi yang dihasilkan.
Gen 16s rDNA memiliki urutan yang lestari pada jarak filogenetik yang luas, namun gen ini juga memiliki poliforfisme yang tinggi pada daerah yang spesifik. Sehingga gen ini bisa digunakan untuk studi identifikasi mikroba. Polimorfisme pada gen $16 \mathrm{~s}$ rDNA akan menghasilkan pola pemotongan yang berbeda antara satu spesies dengan spesies lainnya. Sehingga dapat digunakan untuk membedakan populasi mikroba (Lake, 1997).

Hasil penelitian ini menunjukkan bahwa pada spons pencuci piring telah tumbuh sekurangkurangnya empat jenis bakteri yang berbeda, dimana salah satunya adalah E. coli.E. coli merupakan enterobakter, beberapa galur $E$. coli merupakan bakteri pathogen yang dapat menyebabkan penyakit diare. Untuk bisa mengetahui spesies bakteri lain yang tumbuh, sebaiknya dilakukan perbandingan pola pemotongan dengan bakteri patogen jenis lain.

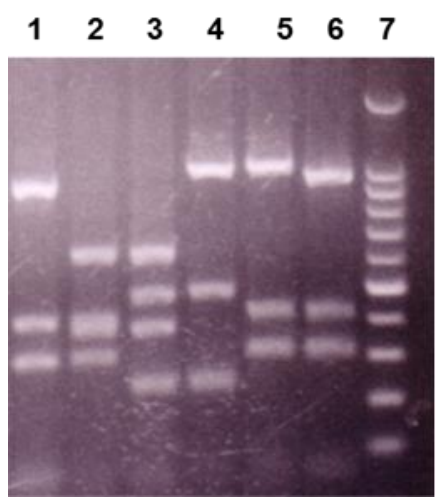

Gambar 4. Karakterisasi hasil RFLP menggunakan enzim Hinf1.Lajur 1 E. coli, lajur 2, 3, 4, 5 dan 6 adalah sampel, lajur 7 Marka DNA. Terlihat bahwa pola pemotongan pada lajur 5 dan 6 sama dengan lajur 1, menunjukkan bahwa kedua sampel itu adalah E. coli.

\section{UCAPAN TERIMA KASIH}

Penulis ingin mengucapkan terima kasih kepada: Kiki Maesarah, Fadli Muhammad, Siti Nur Inayah, Julia Rahmayani, Sri Rejeki dan Dila atas bantuan teknis. Penelitian ini didanai oleh BOPTN Unpad 2012. Penulis mengucapkan terima kasih pada LPPM Unpad dan DIKTI.

\section{DAFTAR PUSTAKA}

Baker G.C., Gaffar S., Cowon D.C., Suharto A.R. (2001). Microbial community analysis of Indonesian hot-springs. FEMS Microbiol. Lett. 200(1): 103-9.

Brugger S.D., Frei L., Frey P.M., Aebi S., Muhlemann K., Hilty M. (2012). 16S rRNA terminal restriction fragment length polymorphism for the characterization of the nasopharyngeal microbiot. Plos. One. 7(12), e52241.

Innis M.T., Gelfand D.H., Sninsky J.J., White J.T. (1990). PCR Protocols, A Guide to Methods and Applications, Academic Press Inc, San Diago. 
Kolbert C.P. and Persing D.H. (1999). Ribosomal DNA sequencing as a tool for identification of bacterial pathogens. Curr.Opin.Microbiol. 2: 299-305.

Lake J.A. (1997). Phylogenetic inference: How much evolutionary history is knowable. Mol. Biol. Evol.14(3): 213-219.

Madigan M.T., Martinko J.M. and Parker J. (2000).Biology of Microorganisms, $9^{\text {th }}$ ed: 432438, Prentice Hall Inc, New Jersey.

Muyzer G. and Ramsing N.B. (1995). Molecular methods to study the organization of microbial communities. Water Sci. Technol. 32, 1-9.

Newton C.R. and Graham, A. (1994). PCR Introduction to Biotechniques, Bios Scientific Publisher Ltd., Oxford.

Nocker A., Burr M. and Camper A.K. (2007). Genotypic microbial community profiling: a critical technical review. Microb Ecol. 54(2): 276-89.

Olsen G.J. and Woese C.R. (1993). Ribosomal RNA: a key to phylogeny. FASEB.7: 113-123.

Savelkoul P. H. M., Aarts H. J. M., de Haas J., Dijkshoorn L., Duim B., Otsen M., Rademaker J.L.W., Schouls L., and Lenstra J.A. (1999). Amplified fragment length polymorphism analysis: the state of an. ar. J. Clin. Microbiol. 37(10): 3083-3091.

Schutte U.M., Abdo Z., Bent S.J., Shyu C., Williams C.J., Pierson J.D., Forney L.I. (2008). Advances in the use of terminal restriction fragment length polymorphism (T-RFLP) analysis of $16 \mathrm{~S}$ rRNA genes to characterize microbial communities. Appl. Mocrobiol. Biotechnol. 80(3): 365-80.

Summarco M.L., Ripabelli G., Tamburro M. (2014). Molecular epidemiology of infectious diseases: analytical methods and results interpretation. Ann. Ig. 26(1): 10-45.doi: 10.7416/ai.

Woese, C.R. (1987). Bacterial evolution. Microbiologycal Reviews. 51(2): 221-271. 